\title{
Spatial dimensions of sustainable energy systems: new visions for integrated spatial and energy planning
}

\author{
Gernot Stoeglehner ${ }^{1 *}$, Nora Niemetz ${ }^{2}$ and Karl-Heinz Kettl ${ }^{2}$
}

\begin{abstract}
The turn to sustainable energy system is a major societal goal at the global level. In this paper, we argue that this radical shift in energy provision towards increased energy efficiency and the use of renewable resources can only be achieved if its spatial dimensions are taken into consideration. Spatial structures have considerable influence on different aspects of the energy demand, and with spatial planning, the resource availability and use are influenced. Further, we propose that different spatial types need different strategies for the implementation of sustainable energy systems and that integrated spatial and energy planning is needed to support this change. Visions for four types of spatial structures: the city, the suburban area, the small town as well as the rural areas define their roles in the "space-resource-planning continuum", which are the foundation to shape an integrated spatial and energy planning system.
\end{abstract}

Keywords: spatial planning, rural development, energy, renewable resources

\section{Background}

As energy systems are key infrastructures of society, they are also an important issue of spatial planning. So far, the link between spatial planning and energy systems is mainly dealing with the problem that the energy provision of the built environment is guaranteed, may it be for residential, commercial or industrial development. Energy is a "hard" factor for zoning, especially for commercial and industrial areas [1]. Besides the fact that energy has to be provided - which usually has no strong restriction because of the possibility to use is easily available and readily transportable fossil energy - the link between spatial planning and energy planning is underdeveloped. We propose to look at spatial planning and energy planning not as distinct "two sides of a coin" but as a continuum because intellectual separation and sectoral analysis leads to sub-optimal solutions. In the project PlanVision ${ }^{\mathrm{a}}$, an analysis of the interactions

\footnotetext{
* Correspondence: gernot.stoeglehner@boku.ac.at

'Department of Spatial, Landscape and Infrastructure Sciences, Institute of Spatial Planning and Rural Development, University of Natural Resources and Life Sciences, Vienna, Peter-Jordan-Straße 82, 1190, Vienna, Austria Full list of author information is available at the end of the article
}

between spatial planning and energy planning was carried out. This is the basis for this paper.

As can be derived from previous studies, there are substantial contributions spatial planning can make in shaping sustainable energy systems. Spatial planning sets frameworks for energy consumption, production and distribution [2], no matter if this is done consciously in planning processes or accidentally - often with negative effects concerning energy efficiency and environmental pressure.

Spatial planning decisions have major impacts on the energy demand of the built environment as well as mobility connected with the spatial structures (see, e.g. [3-7]). Several initiatives of urban planning point out, that energy-efficient settlement structures also lead to a high quality of life and have several features in common like de-centralised concentration, multi-functionality, nearness within walking and/or biking distances as well as certain densities (see, e.g. [8-16]). Although these relations between settlement structures and energy demand are well known, real developments more often do not comply with these concepts which leads to an increase of energy demand even in spite of more energy-efficient buildings, appliances and vehicles (see 
for Austria, e.g. [17-19]). Besides spatial organisation, spatial planning decisions also influence energy demand by choosing sites with a certain topography and exposition as well as by framing the built structures in building schemes (see, e.g. [5,20-24]).

Research has also been done on spatial dimensions of energy conversion and distribution as energy provision (especially in the case of bio-based energy carriers) causes land demand and, therefore, calls for core issues of spatial planning like zoning, securing of land uses and resources as well as minimisation of spatial conflicts. Several studies have contributed to questions which spatial developments, land use conflicts and/or impacts of the utilisation of specific renewable resources might arise (see, e.g. [1,25-28]). Furthermore, process designs for energy planning on the local and regional level have been elaborated. (see, e.g. [29-41]). Within the project PlanVision, an in-depth system analysis of the spatial-resourceplanning continuum was carried out identifying four elements (out of 34), namely multi-functionality, density, siting as well as resources that dominate the system.

The aim of this article is to examine in detail which implications the use of renewable resources for energy supply has for spatial planning. We also include the assumption in our considerations that in the long term also industry might switch to renewable resources and, therefore, additional pressures on limited renewable resources, especially biomass, will arise. Therefore, we will discuss spatial planning implications of an extensive sustainable use of renewable energy and introduce a new vision for the spatial organisation of energy and resource supply under sustainable conditions. Finally, we make a proposal for shaping integrated spatial and energy planning.

\section{Methods}

We develop the train of argument in the following way: First, we define spatial dimensions of sustainable energy systems. From these dimensions we develop a generic vision for spatial development considering a spatialresource-planning continuum. Within this continuum we ascribe functions to four archetypes of spatial structures urban areas, suburban areas, small towns as centres of rural areas as well as rural areas based on the characteristics of different products and services. Furthermore, implications of the vision concerning the four dominating system elements are derived for the four spatial archetypes leading to specific objectives that should guide future planning. Finally, we deduce integrated spatial and energy planning instruments to achieve these objectives.

\section{Spatial dimensions of sustainable energy systems}

Sustainable energy systems, their generation as well as their utilisation are intrinsically linked to spatial management. Contrary to a society based on fossil resources to meet its energy and material demand, a sustainable society based on renewable resources will have to draw on space as its ultimate fundament for wealth. The reason for this prominence of space is that almost all renewable resources, solar radiation, wind and hydro power as well as bio-resources may be tracked back to our ultimate sustainable natural income, solar energy.

Solar energy is the quintessential area-dependent resource. It can only be "harvested" from earth's surface or by harnessing processes, such as wind and water power, that emanate from interaction between solar radiation and earth's surface. This makes spatial management and planning tantamount to resource and energy planning in a sustainable society.

Another aspect of renewable resources is of importance when analysing the link between spatial planning and resource provision: renewable resources are notoriously de-centralised resources. This is of course a logical result of their dependency on space for their generation. Contrary to all fossil (and nuclear) resources that emanate from point resources like mines and wells, renewable resources emerge on every square metre of earth's surface in the form of solar radiation and/or bioresources.

Needless to say that this increased importance of space as the ultimate resource for sustaining life and economic activity of mankind has major implications for spatial planning. Spatial planning and energy planning cannot be separated anymore. From the point of view of planning, the reliance on sustainable energy sources creates a "spatial-resource-planning continuum" that can only be approached in an integrated way.

One particular consequence is the need to guide spatial planning and development according to the functionality of the space involved: the double role of space as the ultimate resource provider as well as habitat for society requires a more differentiated look on different spatial categories and their particular role and development framework.

This is in marked difference to the current situation of a fossil-based society. As these resources are point resources (exploited usually far from areas of intensive human settlement), all spatial elements away from the singular exploitation areas (mines, wells, etc.) have comparable access to external resources. This in turn leads logically to the postulate of equal development opportunities for every location as there are only minor functional requirements in terms of resource management on a spatial level. Economic development is mainly driven by resources that have no immediate link to the space subjected to planning and hence spatial planning (with very few exemptions) is not linked to resource 
management. From a resource point of view in a fossil society, spatial planning deals with a mostly amorphous, unstructured matter.

A differentiated framework for spatial planning from the resource point of view must take into account

- the main characteristics of renewable resources;

- the structure of the distribution pathways for different qualities of energy in particular;

- archetypal categories for spatial development and their functionality within the spatial-resource-planning continuum.

\section{Main characteristics of renewable resources}

Solar radiation is an abundant resource that lacks however the high energy concentration of fossil resources. Harvesting this everlasting energy form therefore requires relatively large areas. A society based on renewable resources will thus have to manage its spatial resources in the most careful way.

Besides requiring space renewable resources by and large show in some cases (solar energy) cyclical and in other cases (wind power) erratic time dependency in their emergence. This requires storage to align energy provision with energy demand. In any case, storage is costly, either in terms of money (e.g. for batteries) or in required area (when biomass is used to "store" solar energy). The imperative to provide storable energy for stabilising energy provision as well as for particular applications (namely mobility) assigns biomass in its various forms a privileged role among other sustainable energy forms. This in turn increases the spatial requirements considerably because biomass has a much lower yield compared to other sustainable energy forms such as thermal solar energy, PV or wind power. The utilisation of arable land as well as forests and hence spatial planning becomes much more intricate in a society based on renewable resources as a result of the intrinsic need for energy from biomass.

Finally logistical considerations become central to the energy system. Many renewable resources (in particular low-grade biomass like grass, wood chips or straw) have low transport densities, in some cases (e.g. wood chips, grass) paired with high humidity. This restricts feasible transport distances considerably, requiring de-central conditioning and/or utilisation of such resources.

Structure of distribution pathways for sustainable energy Besides the characteristics of sustainable energy resources, the structure of distribution pathways is an important factor in the spatial-resource-planning continuum. Different energy qualities such as electricity, heat/cooling energy, gas and oil are distributed via large-scale infrastructures and show widely different ranges and distribution densities. On top of that, energy qualities may be transformed into each other following restrictions defined by laws of nature: electricity may readily be transformed to heat/cooling energy, gas and oil may be partly transformed into electricity but always render heat as a by-product in this transformation, low temperature heat can only be transformed into cooling energy.

Table 1 shows the characteristics of different distribution grids. This table already assumes that these grids are "smart" in the way that they accommodate feed-in from different providers than central sources where appropriate.

\section{Generic visions for spatial development within the spatial-resource- planning continuum}

A sustainable energy-based society requires highly efficient management of the space as the ultimate resource. Efficient management however entails differentiation between spatial elements and insight into the functionality of these elements. A generic categorization of spatial elements within the spatial-resource-planning continuum renders the following four archetypes (Table 1):

- Urban centres

- Suburban areas

- Small towns as centres of rural areas

- Rural areas

These archetypes are assigned vital and widely different functionalities within the spatial-resource-planning continuum. From a resource/product point of view the generic visions - independent from the state of development of the four archetypes and the gap between state and vision - may be described as follows:

Urban centres are the main consumers of energy in all forms. Conversely, they are the main providers of complex (industrial) goods (e.g. electronic devices, machinery, cars, etc.) and services.

Suburban areas form the spatial reserve for urban centres and take over a major supply function for them, namely the supply with fresh products of daily consumption (e.g. high-quality food).

Small towns as centres of rural areas have the function to convert in particular bio-resources into easily transportable commodities and form crucial nodes in the distribution grids for energy, linking them and shifting energy from one to the other (e.g. by using biomass to generate electricity and heat or to generate (bio-)gas that may be distributed via the grid).

Rural areas are the ultimate provider for crucial bioresources, both for sustenance as well as storable energy carriers.

In order to obtain a clearer picture on the interaction between these archetypes, at least on the level of 
Table 1 Characteristics of different energy distribution pathways

\begin{tabular}{|c|c|c|c|c|c|}
\hline \multicolumn{2}{|c|}{ Energy form } & \multirow{2}{*}{$\begin{array}{c}\text { Density } \\
\text { Very high }\end{array}$} & \multirow{2}{*}{$\begin{array}{c}\text { Range } \\
10 \mathrm{~km}\end{array}$} & \multirow{2}{*}{$\begin{array}{l}\text { Feed-in } \\
\text { Everywhere }\end{array}$} & \multirow{2}{*}{$\begin{array}{l}\text { Utilisation } \\
\text { Everywhere }\end{array}$} \\
\hline Electricity & Low voltage & & & & \\
\hline & Medium voltage & High & $50 \mathrm{~km}$ & Everywhere & Everywhere \\
\hline & High voltage & Medium & $500 \mathrm{~km}$ & International, urban centre, suburban, small city & $\begin{array}{l}\text { Urban centre, suburban area, } \\
\text { small town }\end{array}$ \\
\hline \multirow[t]{2}{*}{ Gas } & Low pressure & Very high & $20 \mathrm{~km}$ & $\begin{array}{l}\text { Urban centre, suburban, small town, selectively } \\
\text { in rural areas }\end{array}$ & $\begin{array}{l}\text { Urban centre, suburban area, } \\
\text { small city }\end{array}$ \\
\hline & High pressure & Very low & $1,000 \mathrm{~km}$ & International, urban centre & Urban centre \\
\hline Heat & & Very high & 10 km & Everywhere & Everywhere \\
\hline Oil & & Very low & $1,000 \mathrm{~km}$ & International, urban centre & Urban centre \\
\hline
\end{tabular}

material products, Table 2 provides an overview on what type supplies what product to society.

The nature of the spatial-resource-planning continuum however requires not only to take energy aspects into consideration but to match them with the basic functions the described archetypes have to provide from the social and economic point of view. Taken together these different functions can then be used to provide a comprehensive set of planning goals for sustainable spatial development. Table 3 provides this overview.

In the following sub-chapters the visions for the spatial types are described in more detail along the dominating system elements multi-functionality, density, siting as well as resources as base for the production and distribution of sustainable energy.

\section{Urban centres}

As urban centres are the main user of energy and resources and production areas for primary production are limited, questions regarding the generation of energy take a backseat to those concerning efficiency (including energy saving by structural, technical and behavioural change), distribution and transport. Efficiency is the highest premise for sustainable urban development in order to reduce material and energy input in the first place. This requires also conscious material management, including collection and transport of waste combined with recycling of materials and thermal use which might substantially contribute to the energy supply of the city. In addition to waste a city's resource portfolio may also include solar energy utilisation.

Multi-functional, densely populated areas are an important precondition to guarantee for the efficiency of complex infrastructures like energy supply, public transport, high-quality social infrastructures as well as for economic advantages. Multi-functional and dense areas are also an important precondition for the levelling out of dynamics between consumption and production as well as cascade use of energy over time. Concerning siting and zoning of different land uses on the system level multi-functionality and at least medium dense agglomeration are keys to ensure energy efficiency, both from the mobility point of view as well as according to the preconditions for energy (and resource) cascades. In particular, heat cascading needs short distances (as heat losses in grids are considerable) and diversity in heat quality demand (provided by multi-functionality) to utilise energy in the most efficient way with energy intensive industries at the top of the cascades and residential heat and cool at its bottom. Details like local climate conditions or urban design questions might just lower energy demand and might contribute to fulfil the efficiency paradigm (Table 3 ).

\section{Suburban areas}

In this vision presented here, suburban areas are perceived as spatial reserve for urban areas dedicated to the following functions: primary production of fresh goods with maximum production within environmental capacity limits.

Table 2 Matrix of provision and consumption among archetypical space categories

\begin{tabular}{lll}
\hline Product type & Consumer & Provider \\
\hline Fresh products of daily consumption & Urban centre & Suburban area \\
& Suburban area & Suburban area \\
& Small town/rural centre & Rural area \\
Commodities & Rural area & Rural area \\
Bio-resources for commodities & All & Small town/rural centre \\
Complex industrial goods & Small town/rural centre & Rural area \\
\hline
\end{tabular}


Table 3 Generic visions - elements for spatial categories

\begin{tabular}{|c|c|c|c|c|c|c|c|}
\hline \multirow{2}{*}{$\begin{array}{l}\text { Urban centre } \\
\text { Basic function }\end{array}$} & \multirow[b]{2}{*}{ Goal } & \multicolumn{2}{|l|}{ Suburban area } & \multicolumn{2}{|c|}{ Small town/rural centre } & \multicolumn{2}{|l|}{ Rural area } \\
\hline & & Basic function & Goal & Basic function & Goal & Basic function & Goal \\
\hline \multirow[t]{11}{*}{$\begin{array}{l}\text { Living space for } \\
\text { majority of people }\end{array}$} & $\begin{array}{l}\text { Highest quality of } \\
\text { living }\end{array}$ & $\begin{array}{l}\text { Spatial reserve for } \\
\text { urban centre }\end{array}$ & $\begin{array}{l}\text { Highest logistic } \\
\text { efficiency for } \\
\text { people and goods }\end{array}$ & $\begin{array}{l}\text { Attractive living space } \\
\text { for de-centralised } \\
\text { industrial society }\end{array}$ & $\begin{array}{l}\text { High quality of } \\
\text { living }\end{array}$ & $\begin{array}{l}\text { Sufficient population } \\
\text { density for primary } \\
\text { production and sustenance }\end{array}$ & Basic provision of: \\
\hline & $\begin{array}{l}\text { Sufficient leisure } \\
\text { time opportunities }\end{array}$ & & & & $\begin{array}{l}\text { Excellent leisure } \\
\text { time opportunities }\end{array}$ & & Goods (daily consumption) \\
\hline & $\begin{array}{l}\text { High } \\
\text { environmental } \\
\text { quality }\end{array}$ & & $\begin{array}{l}\text { High } \\
\text { environmental } \\
\text { quality }\end{array}$ & & $\begin{array}{l}\text { Highest } \\
\text { environmental } \\
\text { quality }\end{array}$ & & Education (primary level) \\
\hline & & & & & & & Social services \\
\hline & & & & & & & Cultural services \\
\hline & $\begin{array}{l}\text { Comprehensive } \\
\text { provision of: }\end{array}$ & & Basic provision of: & & $\begin{array}{l}\text { Advanced provision } \\
\text { of: }\end{array}$ & Recreational space & Highest environmental quality \\
\hline & Goods & & $\begin{array}{l}\text { Goods (daily } \\
\text { consumption) }\end{array}$ & & Goods & & \\
\hline & $\begin{array}{l}\text { Education (up } \\
\text { to tertiary } \\
\text { level) }\end{array}$ & & $\begin{array}{l}\text { Education } \\
\text { (primary level) }\end{array}$ & & $\begin{array}{l}\text { Education (up } \\
\text { to secondary } \\
\text { level) }\end{array}$ & & \\
\hline & $\begin{array}{l}\text { Social services } \\
\text { (health/care) }\end{array}$ & & Social services & & $\begin{array}{l}\text { Social services } \\
\text { (health/care)l }\end{array}$ & & Sufficient touristic infrastructure \\
\hline & $\begin{array}{l}\text { Cultural } \\
\text { services }\end{array}$ & & $\begin{array}{l}\text { Cultural } \\
\text { services }\end{array}$ & & $\begin{array}{l}\text { Cultural } \\
\text { services }\end{array}$ & & \\
\hline & Research & & & & Research & & \\
\hline \multirow[t]{3}{*}{$\begin{array}{l}\text { Main energy/ } \\
\text { resource consumer }\end{array}$} & $\begin{array}{l}\text { Highest efficiency } \\
\text { of use }\end{array}$ & & $\begin{array}{l}\text { Highest utilisation } \\
\text { efficiency }\end{array}$ & Resource conversion & $\begin{array}{l}\text { Lowest pressure in } \\
\text { resource } \\
\text { conversion/ } \\
\text { utilisation }\end{array}$ & $\begin{array}{l}\text { Sustainable resource } \\
\text { provision }\end{array}$ & Highest efficiency in space utilisation \\
\hline & $\begin{array}{l}\text { Lowest pressure in } \\
\text { energy provision/ } \\
\text { utilisation }\end{array}$ & & $\begin{array}{l}\text { Lowest pressure in } \\
\text { energy provision/ } \\
\text { utilisation }\end{array}$ & & & & Max. long-term yield per area \\
\hline & $\begin{array}{l}\text { Lowest resource } \\
\text { consumption }\end{array}$ & & $\begin{array}{l}\text { Lowest resource } \\
\text { consumption }\end{array}$ & & $\begin{array}{l}\text { Highest conversion } \\
\text { efficiency }\end{array}$ & & Stable eco systems \\
\hline \multirow[t]{3}{*}{$\begin{array}{l}\text { Provider of complex } \\
\text { (industrial) goods } \\
\text { and services }\end{array}$} & $\begin{array}{l}\text { Highest resource } \\
\text { conversion } \\
\text { efficiency }\end{array}$ & $\begin{array}{l}\text { Space reserve for } \\
\text { provision of } \\
\text { complex goods }\end{array}$ & $\begin{array}{l}\text { Highest resource } \\
\text { conversion } \\
\text { efficiency }\end{array}$ & & $\begin{array}{l}\text { Linking the } \\
\text { distribution grids }\end{array}$ & & $\begin{array}{l}\text { Highest logistical efficiency for } \\
\text { renewable resources and by- } \\
\text { products of conversion processes }\end{array}$ \\
\hline & $\begin{array}{l}\text { Strong societal } \\
\text { interaction }\end{array}$ & $\begin{array}{l}\text { Provision of fresh } \\
\text { goods for urban } \\
\text { centre }\end{array}$ & $\begin{array}{l}\text { Highest efficiency } \\
\text { in space utilisation }\end{array}$ & & & & \\
\hline & $\begin{array}{l}\text { International } \\
\text { interconnectedness }\end{array}$ & & $\begin{array}{l}\text { Maximum long- } \\
\text { term yield per area }\end{array}$ & & & & No resource import \\
\hline
\end{tabular}


Furthermore, suburban regions will provide space for "spillover" complex goods production close to urban centres adhering to the high-efficiency principle like in urban centres.

In our vision, just basic supply should be covered in suburban areas, whereas for more specialised supply demands, the suburban area shall be oriented to the urban centre. Suburban shopping centres or hypermarkets do not comply with our vision as they clearly violate the highest efficiency principle postulated for urban regions (mainly because of the necessary individual mobility induced by them as well as the sealing of productive areas) as well as the necessary multi-functionality in cities by concentrating commerce.

This concept calls for high logistic efficiency for people and goods which means orientation of siting and zoning for the built environment in medium dense mixed use areas located on high-capacity public transport lines as well as siting industrial and commercial facilities for complex products on regional and supra-regional distribution grids (electricity, gas, heat, transport) complying with ideas of de-centralised concentration.

Suburban areas are important locations to produce fresh products for the urban centres (again against the backdrop of highest efficiency for the provision of urban centres) and may as well be the location of autonomous production of energy (especially drawing on solar energy technologies and the wastes from the production of fresh products for cities), whereas suburban areas have little importance for large-scale commodity production.

In this spatial archetype, the restructuring process according to this vision requires the most intense changes of actual developments as suburban areas are arguably the farthest from sustainability considering the spatial-resource-planning continuum.

\section{Small towns as centres of rural areas}

Rural small towns are designated to a completely new role in a renewable resource economy. They become the platform of resource processing for commodities which lies in the nature of renewable resources: as they often have little durability and low transport densities, transport distances have to be kept short from the harvesting area to the sites of transformation into commodities. This is dictated by the need to mitigate land deprivation (by returning nutrients from by-products of biogenic raw material conversion to the land) and to high energy demand for transport of biogenic raw materials and wastes from processing them, usually featuring either low transport densities or high water content or both. In this sense, the utilisation of a renewable resource base means to find an optimum between an "economy of scale" - which means that the bigger the commodity production plant is, the more efficient is the resource conversion - and the "ecology of scale" - the smaller the plant is, the more efficient is the transport logistics [42]. In order to find this optimum in a generic way, we suggest that medium-sized commodity production in small towns might best fulfil this task.

To efficiently produce commodities, rural small towns will become nodes between different grids like information, electricity, transport, district heating. They have labour and supply functions for the regional population (in contrary to suburban areas which are oriented towards the urban centres in most of these aspects). Furthermore, innovation capacity in research in development concerning commodity production has to be built up. As resources differ in different regions, there will be considerable differences in the means and ways commodities are offered. Concerning energy conversion, rural small towns will have to be treated similar to urban centres, meaning that mainly solar energy and thermal energy recovery of waste materials from the commodity production will be the main sources of energy.

Following this vision, rural small towns might become an attractive living environment of a de-centralised industrial society. Efficiency principles apply in particular to resource conversion and optimal management of supply grids, e.g. for the utilisation of material and energy residues from the commodity production. Again, multi-functionality and density are important features to establish to ensure efficiency in energy use like short supply grids for district heating and to sustainable transport. Because of nearness in small towns, transport will often include walking and biking, whereas public transport is mainly important to reach urban centres as well as the surrounding rural villages. The role of siting and zoning can be argued in the line with urban centres.

\section{Rural areas}

In this vision, rural areas have the task of supplying resources for society as supply area of all other spatial types. This is accompanied by securing of daily supply (e.g. food, schools, childcare) as well as by the function as recreation area. The long-term securing of biological productivity and stable ecosystems includes mixed-functions of primary production within environmental capacity limits as well as re-introducing of materials and nutrients from conversion processes and from harvest. In order to utilise "economy of scales", to guarantee efficiency of transport logistics and to utilise waste heat in energy grids, the processing of raw materials on rural sites is not desired in this vision but is concentrated in small towns as centres of rural regions.

Concerning settlements, this means providing living space mainly for the population needed to keep up 
primary production, basic supply and recreational uses. Density for settlements is important in order not to waste bioproductive land and secure ecological compensation areas as well as for organising efficient public transport to small towns and urban centres and other supply infrastructures. It would even be desirable to increase bioproductive areas at the cost of underused sprawl settlements and infrastructures.

\section{Results and discussion}

The generic vision presented above may not only guide planning decisions or provide additional backup of longdesired planning visions like multi-functional settlements, de-centralised concentration, density, nearness, etc. as presented in the introduction section. This vision also adds further notions to terms used in spatial planning. For instance, the concept of multi-functionality is normally addressed to the seven basic spatial functions housing, working, nourishing, recreation, supply and disposal, transport as well as communication [15]. Considering resource use, supply and disposal has to be more specified along the production chain of renewable resources - commodities - convenience products and further re-feeding of residues to production sites. Further notions of multifunctionality or density or zoning are added by the fact that in order to utilise energy most efficiently, the loss of waste heat has to be minimised, which means that energy cascading has to be exhausted. Therefore, district heating is very important which is most efficient in multi-functional and dense areas as reasoned above.

Many aspects to implement the vision presented here can be covered within existing planning schemes especially when it comes to energy-efficient and energy-saving settlement design. Most design principles to reduce energy demand are state-of-the-art in the planning discourse but far from state-of-the-art in planning practice. Dependent on the current status of the planning regulations of a specific country additional planning instruments might be useful to be introduced like legally binding planning objectives for "structural" energy efficiency of settlements, coordination of regional planning, zoning, subsidies, tax payments, possibilities to influence real estate markets, legally binding frames for building schemes like minimum (and maximum) densities, etc.

Additionally, we propose holistic, spatially differentiated energy and resource planning on national, regional and local levels that has to spatially assign resource utilisation and environmental protection measures. Such integrated energy and resource plans should comprise at least the following contents:

- energy-efficiency and energy-saving targets;

- renewable material and energy utilisation targets under consideration of environmental capacity limits, environmentally friendly production techniques and non-use of ecological compensation areas;

- spatially differentiated area based material flows in order to enforce re-introduction of nutrients into primary production areas;

- determination of the demand for energy conversion and distribution facilities.

The demand question for energy conversion and distribution facilities operates on the system level, where necessities, size and technological options are clarified before specific sites are designated and projects developed. In this model, the development consent for energy supply facilities could only be approved if the demand for a certain plant or grid can be derived from the integrated spatial and energy plan. Furthermore, also existing spatial plans like regional plans or local spatial development strategies would be feasible to secure renewable resources by zoning respective areas, whereas the main contents of the integrated energy and resource plans sets the frame for spatial planning and goes beyond its competence.

\section{Conclusions}

The turn towards a renewable resource and energy base of society will introduce new challenges not only for the affected infrastructure systems, but also for spatial planning. These impacts are causes by the nature of renewable, especially biomass-based resources which are characterised, inter alia by low transportation density and short durability if unprocessed. Designing viable supply chains around biomass resources means to structure spatial organisation in a different way with implications for urban and regional planning way beyond the supply infrastructures.

Taking spatial dimensions of the transition to sustainable energy systems into account, major challenges arise, inter alia, (1) in cutting back energy demand by re-designing cities, towns and villages as well as related infrastructures in order to achieve, inter alia, multi-functional, dense and structurally energy-efficient units that allow for energy-efficient individual lifestyles; (2) in enhancing sustainable energy and material resource production by securing sufficient areas and keeping them free of land uses that compromise resource production and utilisation, e.g. by preventing urban sprawl; (3) in guaranteeing for energy and resource production within environmental capacity limits; (4) in a spatial differentiation of energy and resource production and processing according to natural production conditions; (5) in coordinating energy and resource planning and spatial planning to reach optimal exploitation of already conversed energy by cascading and the connection of different grids. 
With the visions for the spatial-resource-planning continuum, we draft a potential future for managing this transition to a renewable resource base and to sustainable energy systems. The inevitable transition to a sustainable resource base, with resources that are both limited and linked to spatial conditions, requires profound change in planning practice as resource constraints might become dominating guardrails for human development. Spatial structures set effective frameworks for resource systems both on the demand and the supply side, which at the moment often do not comply with resource efficiency. Spatial structures are, although not unchangeable, persisting over time, so that a re-direction of practised planning paradigms towards more sustainable spatial development is pivotal for society.

\section{Endnotes}

${ }^{\mathrm{a}, \mathrm{b}}$ Stöglehner G, Narodoslawsky M, Steinmüller H, Steininger K, Weiss M, Mitter H, Neugebauer GC, Weber G, Niemetz N, Kettl K-H, Eder M, Sandor N, Pflüglmayer B, Markl B, Kollmann A, Friedl C, Lindorfer J, Luger M, Kulmer V: PlanVision - Visionen für eine energieoptimierte Raumplanung. Projektendbericht. Gefördert aus Mitteln des Klima- und Energie-fonds. Wien; (2011) [not published yet].

\section{Acknowledgements \\ The research presented here was carried out under the project "PlanVision"b funded by the Austrian Climate and Energy Fund and carried out within the programme "NEUE ENERGIEN 2020" (grant number 818916). We thank our fellow researchers Michael Weiss, Hermine Mitter, Georg Neugebauer and Gerlind Weber from the Institute of Spatial Planning and Rural Development, Department of Spatial, Landscape and Infrastructure Sciences, University of Natural Resources and Life Sciences; Michael Narodoslawsky, Michael Eder and Nora Sandor from the Institute of Process and Particle Engineering of the Graz University of Technology; Horst Steinmüller, Barbara Pflüglmayer, Beatrice Markl, Andrea Kollmann, Christina Friedl, Johannes Lindorfer and Martin Luger from the Energieinstitut an der Johannes Kepler Universität Linz $\mathrm{GmbH}$ as well as Karl Steininger and Veronika Kulmer from the Wegener Center für Klima und globalen Wandel of the Karl-Franzens- Universität Graz.}

\section{Author details}

'Department of Spatial, Landscape and Infrastructure Sciences, Institute of Spatial Planning and Rural Development, University of Natural Resources and Life Sciences, Vienna, Peter-Jordan-Straße 82, 1190, Vienna, Austria ${ }^{2}$ Institute for Process- and Particle Engineering, Graz University of Technology, Inffeldgasse 21a, 8010 Graz, Austria

\section{Authors' contributions}

All authors contributed - among others (see endnotes ${ }^{\mathrm{a}, \mathrm{b}}$ ) - to the PlanVision project which is the base for this paper. GS was project manager, NN and KHK were project team members. The article was jointly elaborated between the authors.

\section{Competing interests}

The authors declare that they have no competing interests.

Received: 7 September 2011 Accepted: 21 November 2011 Published: 21 November 2011

\section{References}

1. Narodoslawsky M, Stoeglehner G (2010) Planning for local and regional energy strategies with the ecological footprint. J Environ Pol Plann 12(4):363-379

2. Stöglehner G (2009) Energieversorgung als Aufgabe der Raumplanung perspektiven aus Österreich. 15. Thüringer Regionalplanertagung, 2009, Sept 24-25 www.arl-net.de

3. Dittmar H, Ohland G (2004) The new transit town: best practices in transitoriented development. Washington DC: Island Press

4. Motzkus A-H (2002) Dezentrale Konzentration - Leitbild für eine Region der kurzen Wege? Auf der Suche nach einer verkehrssparsamen Siedlungsstruktur als Beitrag für eine nachhaltige Gestaltung des Mobilitätsgeschehens in der Metropolregion Rhein-Main. Bonner Geographische Abhandlungen 107

5. Prehal A, Poppe H (2003) Siedlungsmodelle in Passivhausqualität. Berichte aus Energie- und Umweltforschung 1/2003. Wien: Bundesministerium für Verkehr, Innovation und Technologie

6. Register R (2002) Ecocities: building cities in balance with nature. Berkeley: Berkeley Hills Books

7. Schriefl E, Schubert U, Skala F, Stoeglehner G (2009) Urban development for carbon neutral mobility. World Transport Pol Pract 14(4):25-35

8. Brunner O, Gutmann R, Lung E, Mayerhofer R, Skala F (1999) Forderungen für die Realisierung einer ausgewogenen Nutzungsmischung bei der Siedlungsentwicklung. In: Wachten K, Brunner O, Kaiser H-J (eds) Kurze Wege durch die Nutzungsmischung. Grundlagen für eine nachhaltige siedlungsentwicklung. Linzer Planungsinstitut: Linz

9. Congress for the new urbanism: charta des new urbanism.http://www.cnu. org/sites/www.cnu.org/files/Charta_deutsch.pdf

10. Farr D (2008) Sustainable urbanism: urban design with nature. Hoboken: Wiley

11. Gaffron P, Huismans G, Skala F (2005) Ecocity book I: a better place to live. Vienna: Facultas Verlags- und Buchhandels AG

12. Gaffron P, Huismans G, Skala F (2008) Ecocity Book II: how to make it happen. Vienna: Facultas Verlags- und Buchhandels AG

13. Kanatschnig D, Weber G (1999) Nachhaltige Raumentwicklung in Österreich. Schriftenreihe des österreichischen Instituts nachhaltige Entwicklung, Band 4, Wien

14. Lerch D (2007) Post carbon cities: planning for energy and climate uncertainty. a guidebook on peak oil and global warming for local governments, post carbon institute. Post Carbon Press, Sebastol, US http:// postcarboncities.net

15. Lienau C (1995) Die Siedlungen des ländlichen Raumes. Braunschweig: Westermann Schulbuchverlag $\mathrm{GmbH}, 2$

16. Newmann P, Jennings I (2008) Cities as sustainable ecosystems. Washington DC: Island Press

17. Dallhammer E (2008) Verkehrsbedingte treibhausgase. Die Verantwortung der Siedlungspolitik. RAUM 71:37-39

18. Steininger KW (2008) Raumplanung als Emissionsbremse. Großes Potenzial in der Theorie, wenig Effizienz in der Praxis. RAUM 71:22-26

19. Stöglehner G, Grossauer F (2009) Raumordnung und Klima. Die Bedeutung der Raumplanung für Klimaschutz und Energiewende. Wissenschaft und Umwelt - Interdisziplinär 12:137-142

20. Bruck M, Geissler S, Lechner R (2002) Total Quality Planung und Bewertung (TQ-PB) von Gebäuden. Leitfaden. Projektbericht im Rahmen der Programmlinie Haus der Zukunft. Impulsprogramm Nachhaltig Wirtschaften. Vienna: Bundesministerium für Verkehr, Innovation und Technologie

21. Heinze M, Voss K (2009) Ziel Null Energie. Erfahrungen am Beispiel der Solarsiedlung Freiburg am Schlierberg. Deutsche Bauzeitschrift, Jg 57(1):72-74

22. Neufert E (2009) Bauentwurfslehre. Grundlagen, Normen, Vorschriften über Anlage, Bau, Gestaltung, Raumbedarf, Raumbeziehungen, Maße für Gebäude, Räume, Einrichtungen, Geräte mit dem Menschen als Maß und Ziel. Handbuch für den Baufachmann, Bauherrn, Lehrenden und Lernenden. Wiesbaden: Vieweg+Teubner and GWV Fachverlage GmbH, 39

23. Tappeiner G, Koblmüller M, Staffler G, Walch K (2002) Heimwert. Ökologisch-ökonomische Bewertung von Siedlungsformen. Berichte aus der Energie- und Umweltforschung 25/2002. Vienna: Bundesministerium für Verkehr, Innovation und Technologie

24. Treberspurg M (1999) Neues Bauen mit der Sonne. Ansätze zu einer klimagerechten Architektur. Vienna: Springer, 2 
25. Birnstingl B, Narodoslawsky M, Zachhuber C, Krotscheck C, Selvicka E, Lauber V, Riebenbauer L (2007) Endbericht des Projektes Landwirtschaft 2020, Program Energy systems of tomorrow. Federal Ministry of Transport, Innovation and Technology, Vienna, Austria http://www. energiesystemederzukunft.at/results.html/id4660

26. Eder P, Narodoslawsky M (1999) What environmental pressures are a region's industries responsible for? A method of analysis with descriptive input/output models. Ecol Econ 29:359-374

27. Halász L, Zachhuber C, Narodoslawsky M (2006) Beyond processes application of process synthesis to the optimisation of regional economies. CHISA 2006, 2006 August 27-31; Prague

28. Mandl M, Gwehenberger G, Narodoslawsky M, Krotscheck C, BirnstinglGottinger B (2008) Projektbericht des Projektes KOMEOS, Program Energy systems of tomorrow. Federal Ministry of Transport, Innovation and Technology, Vienna, Austria http://www.energiesystemederzukunft.at/

29. Girardin L, Marechal F, Dubuis M, Calame-Darbellay N, Favrat D (2010) EnerGis: a geographical information based system for the evaluation of integrated energy conversion systems in urban areas. Energy 35:830-840

30. Ferng JJ (2002) Toward a scenario analysis framework for energy footprints. Ecol Econ 40:53-69

31. Haberl H (2006) The global socioeconomic energetic metabolism as a sustainability problem. Energy 31:87-99

32. Joanneum Research (2001) Handbuch für kommunale und regionale Energieplanung (KREP 2000) [Handbook municipal and regional energy planning]. Graz: Joanneum Research

33. Kanning H, Buhr N, Steinkraus K (2009) Erneuerbare Energien - Räumliche Dimensionen, neue Akteurslandschaften und planerische (Mit) Gestaltungspotenziale am Beispiel des Biogaspfades. Raumforschung und Raumordnung 67(2):142-156

34. Krotscheck C, Narodoslawsky M (1996) The sustainable process index. a new dimension in ecological evaluation. Ecol Eng 6:241-258

35. Medved S (2006) Present and future ecological footprint of Slovenia - the influence of energy demand scenarios. Ecol Model 192:26-36

36. Rode MW, Kanning H, (Eds) (2010) Natur- und raumverträglicher Ausbau energetischer Biomassepfade. Stuttgart: Ibidem-Verlag

37. Späth P (2007) EnergieRegionen: Wirksame Leitbildprozesse und Netzwerke zur regionalen Gestaltung sozio-technischen Wandels. Vienna: BMVIT Berichte aus Energie- und Umweltforschung 29/2007

38. Stöglehner $\mathrm{G}$ (2003) Ecological footprint - a tool for assessing sustainable energy supplies. Journal of Cleaner Production 11:267-277

39. Stoeglehner G, Narodoslawsky M (2008) Implementing ecological footprinting in decision-making processes. Land Use Pol 25:421-431

40. Stoeglehner G, Narodoslawsky M (2009) How sustainable are biofuels? Answers and further questions arising from an ecological footprint perspective. Bioressource Technology 100:3825-3830

41. Stremke S (2010) Designing sustainable energy landscapes. Thesis. Wageningen University

42. Gwehenberger G, Narodoslawsky M, Liebmann B, Friedl A (2007) Ecology of scale versus economy of scale of bioethanol production. Biofuels Bioprod Bioref 1(4):264-269. doi:10.1002/bbb.35

doi:10.1186/2192-0567-1-2

Cite this article as: Stoeglehner et al: Spatial dimensions of sustainable energy systems: new visions for integrated spatial and energy planning. Energy, Sustainability and Society 2011 1:2

\section{Submit your manuscript to a SpringerOpen ${ }^{\mathcal{O}}$ journal and benefit from:}

- Convenient online submission

- Rigorous peer review

- Immediate publication on acceptance

- Open access: articles freely available online

- High visibility within the field

- Retaining the copyright to your article

Submit your next manuscript at $\gg$ springeropen.com 